\title{
症例報告
}

サイトメガロウイルス関連血球貪食症候群および肺炎を併発した全身性エリテマトーデス

田中康 博*2, 瀬尾龍太郎*1, 永 井 雄 也*1, 森 美奈子*1

戸上勝化 ${ }^{* 1}$, 藤田晴之*1, 倉田雅之*1, 松下章子*1

前田明則*1，永井謙一*1，小谷宏行*3，高橋隆 ${ }^{*}{ }^{*}{ }^{*}$

\section{Systemic lupus erythematosus complicated by cytomegalovirus-induced hemophagocytic syndrome and pneumonia}

\author{
Yasuhiro TANAKA ${ }^{* 2}$, Ryutaro SEO ${ }^{* 1}$, Yuya NAGAI ${ }^{* 1}$, Minako MORI ${ }^{* 1}$, \\ Katsuhiro TOGAMI ${ }^{* 1}$, Haruyuki FuJita ${ }^{* 1}$, Masayuki Kurata ${ }^{* 1}$, Akiko MATSUSHITA ${ }^{* 1}$, \\ Akinori MAEDA $^{* 1}$, Kenichi NAGAI ${ }^{* 1}$, Hiroyuki KOTANI ${ }^{* 3}$ and Takayuki TAKAHASHI ${ }^{* 1}$ \\ ${ }^{*}$ Department of Hematology and Clinical Immunology, Kobe City Medical Center General Hospital, Japan \\ ${ }^{*}$ Yasuhiro Tanaka is currently at the Department of Hematology and Oncology, \\ Graduate School of Medicine, Kyoto University, Japan \\ ${ }^{*}$ Department of Medicine, Kobe-Japan Post Hospital
}

(Received November 29, 2007)

summary

A 58-year-old female with systemic lupus erythematosus (SLE) and anti-phospholipid syndrome (APS) was referred and admitted to our hospital because of fever and pancytopenia. She had been taking small dose of prednisolone and azathiprine since 2003 with stable SLE and APS. Two weeks before the admission, she developed fever and common cold-like symptoms and was admitted to a hospital. Antibiotics were ineffective and thrombocytopenia manifested. Under a diagnosis of progressive SLE, bolus methylprednisolone was administrated. However, she became pancytopenic and was transferred to our hospital. A bone marrow aspirate showed the hemophagocytosis and chest CT scanning revealed interstitial pneumonia. Cytomegalovirus (CMV) antigenemia test gave a positive result. A diagnosis of CMV-induced hemophagocytic syndrome (HPS) and CMV pneumonia was made. Gancyclovir resolved the pancytopenia, pneumonia, and fever. There have been only 3 reported cases of CMV-related HPS in collagen disease.

Key words _ cytomegalovirus; hemophagocytic syndrome; interstitial pneumonia; systemic lupus erythematosus; gancyclovir

抄 録

症例は 58 歳の女性. 31 歳より全身性エリテマトーデス（SLE）抢よび抗リン脂質抗体症候群（APS）のため prednisolone と azathioprine を内服し SLE とAPS は安定していた. 2004 年 10 月, 発熱を伴う感冒様症状が出現 したので近医に入院．抗生剤は無効で血小板減少が出現したので，SLEの増悪との診断のもとステロイドパルス 療法が施行された。しかし，汎血球減少へと進展したので当院へ転院となった。骨髄穿刺で血球頜食像が認めら れ，胸部 CT で肺門部を中心とするスリガラス影が認められた。同日の cytomegalovirus (CMV) antigenemia が陽 性であった。以上より，CMV 関連血球貪食症候群（hemophagocytic syndrome；HPS）抢よび CMV 肺炎と診断. azathioprine を中止し prednisolone を減量して gancyclovir を開始.これにより解熱し沉血球減少は改善した. 現 在, 外来通院中で CMV 感染の再発を認めていない.SLE などの膠原病に CMV 関連 HPS を併発することは稀で あるため報告する。

*1神戸市立医療センター中央市民病院免疫血液内科

*2京都大学医学部血液腫瘍内科

*3神戸逓信病院内科

\section{緒言}

systemic lupus erythematosus (SLE) は多臓器に 病変を来す自己免疫疾患でしばしば anti-phospholipid syndrome (APS) を合併する1). SLEに対し ては prednisolone（PSL）が有効であるが，不応性 
の場合には免疫抑制剂の併用，あるいは大量 methylprednisolone (mPSL) の点滴投与 (mPSL パルス療法）が行われる2)。この免疫抑制剤の併用 や mPSL パルス療法は免疫不全状態を招来し, 種 々の感染症，特に日和見感染が問題となってきた ${ }^{3)}$.

cytomegalovirus (CMV) は日和見感染症の原因 ウイルスのひとつである. 健常者での初感染では一 過性の急性肝障害や伝染性単核球症を引き起こす が4)，免疫不全状態では腸，肺，中枢神経系，眼な ぞの全身蔵器に重篤な炎症を引き起こし，時に致命 的になる5). 近年, SLE などの膠原病に対する免疫 抑制療法の普及により CMV 感染が問題となってき たため迅速な診断抢よび治療が必要となりつつあ る3).

今回, 我々はPSL と azathioprine を併用して いた APS 合併 SLE 患者が MPSL パルス療法後 に, 膠原病では稀な CMV 関連血球領食症候群 （hemophagocytic syndrome；HPS）を発症したの で報告する.

\section{症例}

患 者 : 58 歳, 女性, 主婦.

主 訴: 発熱.

既往歴：58 歳よりステロイド糖尿病のためイン シュリン療法中.

家族歴 : 特記事項なし

現病歴：1977 年（31 歳時）にSLE と診断され近 医に通院していた。 2003 年 2 月に左後頭葉に脳硬 塞を発症し精査の結果，APS の併発が明らかとな った。同年 5 月よりステロイド糖尿病のためPSL は $5 \mathrm{mg} /$ day に減量され, azathioprine $50 \mathrm{mg} /$ day が併用された。これにより SLE と APS は安定して いた. 2004 年 10 月 17 日より発熱抢よび感冒様症 状が出現したため 10 月 20 日近医に入院した.PSL が $30 \mathrm{mg} /$ day に増量され抗生剂投与が行われたが 解熱はみられなかった。 入院時には白血球（WBC） 数 $1.2 \times 10^{9} / \mathrm{L}$ ，へモグロビン $(\mathrm{Hb})$ 濃度 $11.2 \mathrm{~g} / \mathrm{dl}$, 血小板 $(\mathrm{PIt})$ 数 $111.0 \times 10^{9} / \mathrm{L}$ であったが 10 月 26 日には WBC $1.3 \times 10^{9} / \mathrm{L}, \mathrm{Hb} 9.0 \mathrm{~g} / \mathrm{dl}$, Plt $91.0 \times 10^{9} /$ L と血球減少が進行したためSLE の増悪との診断 のもと, 同日より mPSL $1 \mathrm{~g} /$ day によるパルス療法 が開始された。しかし，発熱は持続し，11月 1 日 には WBC $1.1 \times 10^{9} / \mathrm{L}, \mathrm{Hb} 9.1 \mathrm{~g} / \mathrm{dl}$, Plt $76.0 \times 10^{9} / \mathrm{L}$ と汎血球減少が進行したため 11 月 2 日当院へ転院 となった。
入院時現症：身長 $162 \mathrm{~cm}$ ，体重 $65 \mathrm{~kg}$ ，体温 38.6 ${ }^{\circ} \mathrm{C}$, 血圧 $146 / 60 \mathrm{mmHg}$, 脈拍 109 /分, 経皮酸素飽 和度 $\left(\mathrm{SpO}_{2}\right) 95 \%$ (room air). 意識清明, 眼瞼結 膜は貧血様で, 表在リンパ節は触知しなかった。 聴 診上肺に異常は認めず，心音は克進していたが雑音 は聴取しなかった. 肝は右肋弓下 $2.5 \mathrm{~cm}$ 触知した が脾は触知しなかった。両下肢に軽度の浮腫を認め た．神経学的には異常所見を認めなかった.

検査所見（表 1）：入院時の血液検査では WBC $1.3 \times 10^{9} / \mathrm{L}$ (metamyelocyte $1 \%$, band $34 \%$, segment $14 \%$, lymphocyte $45 \%$, monocyte $3 \%$, atypical lymphocyte $3 \%$ ), Hb $9.2 \mathrm{~g} / \mathrm{dl}$, Plt $90.0 \times 10^{\%} / \mathrm{L}$ と汎血 球減少を認めた。CRP は $10.9 \mathrm{mg} / \mathrm{dl}, \quad \mathrm{LDH}$ は 498 IU/L と共に上昇を認めた。 GOT $66 \mathrm{IU} / \mathrm{L}$, GPT 80 IU/L, $\gamma$-GTP $270 \mathrm{IU} / \mathrm{L}$, Alp $498 \mathrm{IU} / \mathrm{L}$ と軽度の肝 胆道系障害を認めた。免疫学的検査では IgG 605 $\mathrm{mg} / \mathrm{dl}, \operatorname{IgA} 67 \mathrm{mg} / \mathrm{dl}, \mathrm{IgM} 108 \mathrm{mg} / \mathrm{dl}$ と免疫グロブ リンの低下を認めた。抗核抗体と抗 RNP 抗体は陽 性で補体の低下は認めず，抗 DNA 抗体も陰性であ ったためSLEの活動性は低いと考えられた。ま た, フェリチン $3285 \mathrm{ng} / \mathrm{ml}$, soluble interleukin-2 receptor $(\mathrm{sIL}-2 \mathrm{R}) 4540 \mathrm{U} / \mathrm{ml}$, interferon- $\gamma(\mathrm{IFN}-\gamma)$ $151 \mathrm{pg} / \mathrm{ml}$, interleukin-18 (IL-18) $3860 \mathrm{pg} / \mathrm{ml}$ とい ずれも高值であった。

腹部超音波検査と $\mathrm{CT}$ 撮影では軽度の脾腫を認め た。骨髄検査ではマクロファージに領食された赤血 球や血小板が認められた（図 1). 胸部単純レント ゲンでは右 cost-phrenic angle の鈍化と右下肺野に 浸潤陰影を認めた。胸部 high-resolution CT では右 下肺野に bronchovascular bundle の肥厚と, 肺門部

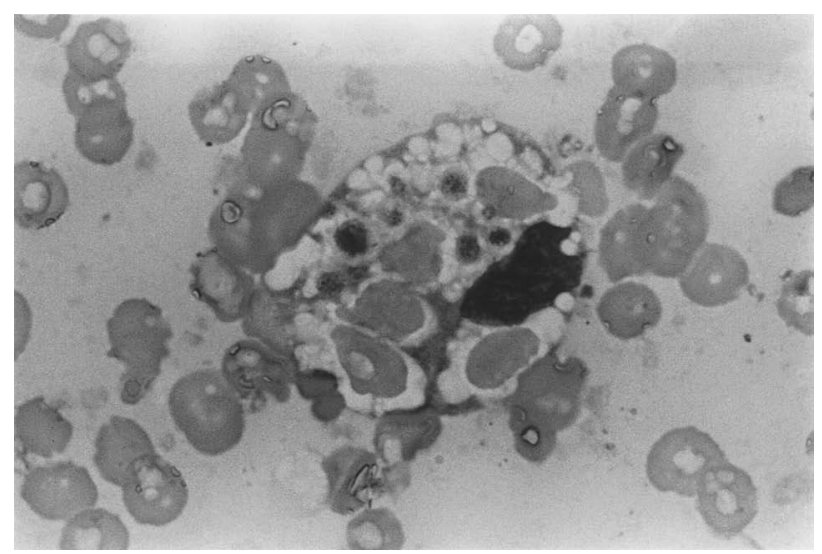

図 1 骨髄中の血球領食像. マクロファージの細胞質中に赤 血球, 血小板が貪食され, 食胞形成がみられる。 Wright-Giemsa 染色, $\times 1,000$. 
表 1 入院時検査所見

\begin{tabular}{|c|c|c|c|c|c|}
\hline WBC & $1.3 \times 10^{9} / \mathrm{L}$ & Glucose & $137 \mathrm{mg} / \mathrm{dl}$ & $\operatorname{IgG}$ & $05 \mathrm{mg} / \mathrm{dl}$ \\
\hline metamyel & $1.0 \%$ & $\mathrm{TP}$ & $4.8 \mathrm{~g} / \mathrm{dl}$ & $\operatorname{IgA}$ & $67 \mathrm{mg} / \mathrm{dl}$ \\
\hline Band & $34.0 \%$ & Alb & $2.8 \mathrm{~g} / \mathrm{dl}$ & $\operatorname{IgM}$ & $08 \mathrm{mg} / \mathrm{dl}$ \\
\hline Seg & $14.0 \%$ & T-bil & $0.7 \mathrm{mg} / \mathrm{dl}$ & $\mathrm{C}_{3}$ & $72 \mathrm{mg} / \mathrm{dl}$ \\
\hline Lym & $45.0 \%$ & $\mathrm{CHE}$ & $202.0 \Delta \mathrm{pH}$ & $\mathrm{C}_{4}$ & $28 \mathrm{mg} / \mathrm{dl}$ \\
\hline Mon & $3.0 \%$ & GOT & $66 \mathrm{IU} / 1$ & $\mathrm{CH}_{50}$ & $8.0 \mathrm{u} / \mathrm{ml}$ \\
\hline atypical Lym & $3.0 \%$ & GPT & $80 \mathrm{IU} / 1$ & 抗核抗体 $(+)$ & $(27.3)$ \\
\hline $\mathrm{RBC}$ & $2760 \times 10^{9} / \mathrm{L}$ & $\gamma-\mathrm{GTP}$ & $270 \mathrm{IU} / 1$ & LE test $(-)$ & \\
\hline $\mathrm{Hb}$ & $9.2 \mathrm{~g} / \mathrm{dl}$ & ALP & $303 \mathrm{IU} / 1$ & 抗 DNA 抗体 $<$ & $5 \mathrm{IU} / \mathrm{ml}$ \\
\hline $\mathrm{Ht}$ & $26.6 \%$ & $\mathrm{LDH}$ & $498 \mathrm{IU} / 1$ & 抗 Sm 抗体（+ - ） & $(23.5)$ \\
\hline Plt & $90 \times 10^{9} / \mathrm{L}$ & UA & $3.0 \mathrm{mg} / \mathrm{dl}$ & 抗 RNP 抗体（+） & $(21.4)$ \\
\hline \multirow[t]{2}{*}{ Ret } & \multirow[t]{2}{*}{$21 \%$} & BUN & $8 \mathrm{mg} / \mathrm{dl}$ & 抗 SS-A 抗体 $(+-$ - ) & $(26.4)$ \\
\hline & & $\mathrm{Cr}$ & $0.6 \mathrm{mg} / \mathrm{dl}$ & \multicolumn{2}{|l|}{ 抗 SS-B 抗体（- ） } \\
\hline PT (INR) & 1.02 & CRP & $10.9 \mathrm{mg} / \mathrm{dl}$ & \multicolumn{2}{|c|}{ Lupus anticoagulant $(-)$} \\
\hline APTT & $31.5 \mathrm{sec}$ & $\mathrm{HbA1c}$ & $7.8 \%$ & \multicolumn{2}{|c|}{ 抗 $\beta_{2} \mathrm{GP} 1$ 抗体（-） } \\
\hline Fib & $404 \mathrm{mg} / \mathrm{dl}$ & $\mathrm{Fe}$ & $23 \mu \mathrm{g} / \mathrm{dl}$ & \multicolumn{2}{|l|}{ 骨髄検査： } \\
\hline D-dimer & $3.8 \mu \mathrm{g} / \mathrm{ml}$ & UIBC & $135 \mu \mathrm{g} / \mathrm{dl}$ & 有核細胞数 & $\times 10^{4} / \mu 1$ \\
\hline AT-III & $77.2 \%$ & Ferritin & $3285 \mathrm{ng} / \mathrm{ml}$ & 巨核球数 & $44 / \mu \mathrm{l}$ \\
\hline \multirow[t]{4}{*}{ FM test $(-)$} & & SIL-2R & $4540 \mathrm{U} / \mathrm{ml}$ & $\mathrm{M} / \mathrm{E}$ 比 & 0.86 \\
\hline & & IL-18 & $3860 \mathrm{pg} / \mathrm{ml}$ & 赤芽球 & $43.2 \%$ \\
\hline & & IFN $-\gamma$ & $151 \mathrm{pg} / \mathrm{ml}$ & 顆粒球 & $37.2 \%$ \\
\hline & & & & \multicolumn{2}{|l|}{ 悪性細胞は認めず } \\
\hline
\end{tabular}

$\mathrm{C}_{3}, \mathrm{C}_{4}, \mathrm{CH}_{50}$ の正常範囲は各々 65-135, 13-35, 29-48. sIL-2R (soluble IL-2 receptor),IL-18 および IFN (interferon)- $\gamma$ の正常值は各々 450, 211, 20.6 以下.

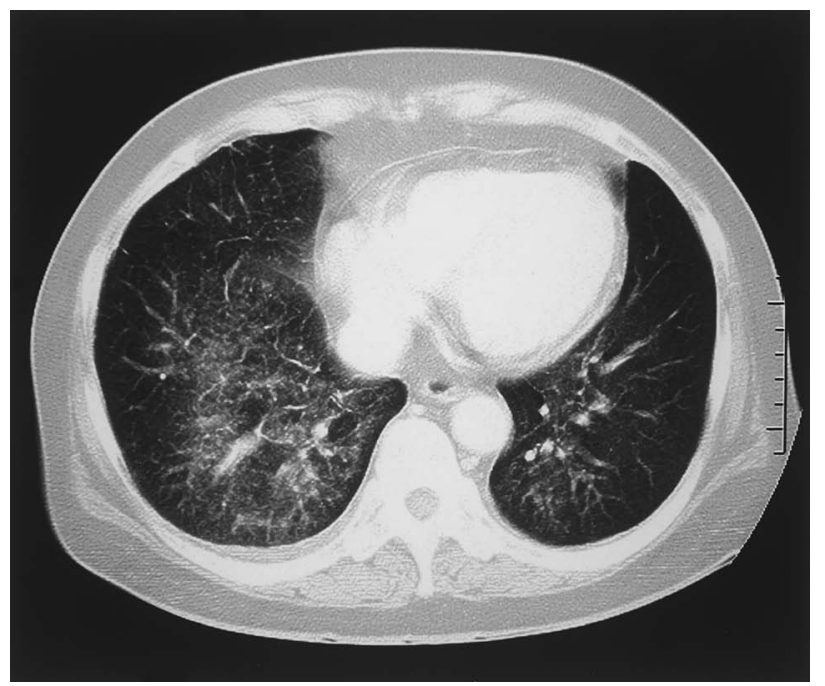

図 2 肺 CT 像（high resolution）。肺門部を中心にスリガラ ス様陰影が認められる.

を中心とするスリガラス様陰影を認めた（図 2）.

11 月 5 日の CMV antigenemia が WBC 15 万個あた り $101 / 97$ 細胞と強陽性であったため CMV 関連 HPS 抢よび CMV 肺炎と診断した。

\section{臨床 経 過}

入院後, azathioprine を中止して PSL $20 \mathrm{mg} /$ day
を継続し 11 月 6 日より gancyclovir $500 \mathrm{mg} /$ day 点 滴静注を開始. これによって白血球および血小板減 少は速やかに改善し，11月 11 日には CMV antigenemia は陰性化し，11月 12 日には解熱した。 胸部レントゲン所見は改善し 11 月 18 日には CT 撮 影でも肺野陰影は消失した. gancyclovir 投与は計 2 週間継続した。PSL は $15 \mathrm{mg} /$ day に減量し，11月 20 日退院となった。以後, 再燃を認めていない。

\section{考察}

本症例の場合, 汎血球減少の原因として薬剂性血 球減少, 血球領食症候群, および SLE の増悪が考 えられた. azathioprine を中止しても血球減少は改 善せず，理学所見，症状および免疫学的検査所見よ りSLEの増悪は否定的で, 骨骾検査で血球頜食像 を認めたため血球貪食が血球減少の原因と考えられ た. HPS は家族性と反応性に大別され, 反応性は さらに薬剂, 感染症, 腫瘍抢よび膠原病関連に分類 される，感染症関連 HPS はさらにウイルス性，細 菌性，結核性などに細分類される。ウイルス性 HPS の原因ウイルスとしては Epstein-Barr virus, herpes virus, CMV, human parvovirus B19 など多岐 にわたる ${ }^{6)}$. 本例の場合, 病歴聴取より家族性は否 
定的であるため反応性であり，上記のように SLE の活動性は乏しいため膠原病関連は否定的で，薬剂 関連も考えにくい状況であった。一方，CT で間質 性肺炎を認め, CMV antigenemia が陽性で, sIL2R および IFN- $\gamma$ も高值であったため CMV による HPS と診断した. CMV 感染の要因として前医での mPSL パルス療法が考えられるが，パルス療法前に すでに血小板減少が認められており, 少量の PSL と azathioprine の服用に加えてインシュリンを必要 とする糖尿病を併発していたことを考慮するとこ の時点で CMV 感染症および CMV 関連 HPS を発 症していた可能性は否定できない，Ho らは臓器移 植後において CMV の再活性化は PSL のみでは生 じにくく，免疫抑制剤の投与によって生じやすい と報告しており4)，森らは inflammatory connective tissue diseaseに抢いても同様の報告をしている33). また， azathioprineを内服していた Crohn 病の小児 患者に CMV 関連 HPS を発症したという報告もあ る7)。すなわち, azathioprine は CMV 感染のリス クファクターの 1 つであることが示唆される.

CMV によるHPS は成人 $\mathrm{T}$ 細胞性白血病や臓器 移植後の合併症として散見されるが8 10)，本例のよ うに膠原病に合併した報告は 3 例のみであ $3^{5,11,12)}$. 基礎疾患として, 1 例は本例と同様に SLE で5), 残りは各々, 成人発症 Still 病 ${ }^{11)}$, 関節リ ウマチ12)である。そのうち 2002 年に Sakamoto ら はSLE に合併した CMV 腸炎および HPS の症例を 報告しているが，その患者は死亡しており5)， CMV 感染症に伴う HPS は致命的になり得ること を示唆しており，注意が必要である.

CMV 感染の検査方法としては CMV antigenemia 法13)のほかに shell vial 法やPCR によるウイルス量 測定がある14)。この中で, shell vial 法や PCR 法は 高感度のために偽陽性が多く, 必ずしも臨床病態々 相関しない14)。一方, antigenemia 法は感度が高く 偽陽性率が少なく臨床病態とも相関し ${ }^{14)}$, 迅速に結 果が得られるため 3 つの中で最も有用と考えられ る. 辻らは 2001 年に CMV antigenemia 法が膠原病 に合併した CMV 感染症の早期診断に有用であった と報告している15)。 今後, 膠原病で免疫不全状態に ある患者では CMV 感染に注意を払い，疑われる場 合には CMV antigenemia を早期に測定する必要が ある。

\section{文献}

1) Ruiz-Irastorza, et al. : Systemic lupus erythematosus. Lancet 357 : 1027-1032, 2001.

2) Toubi, E., et al. : Systemic lupus erythematosus vasculitis : a current therapeutic overview. Curr. Treat. Options Cardiovasc. Med. 6 : 8797, 2004.

3) Mori, T., et al. : Incidence of cytomegalovirus reactivation in patients with inflammatory connective tissue diseases who are under immunosuppressive therapy. J. Rheumatol. 31 : 1349-1351, 2004.

4) Ho, M.: Observations from transplantation contributing to the understanding of pathogenesis of CMV infection. Transplant. Proc. 23 (Suppl 3) : 104-109, 1991.

5) Sakamoto, O., et al. : Systemic lupus erythematosus complicated by cytomegalovirus-induced hemophagocytic syndrome and colitis. Intern. Med. 41 : 151-155, 2002.

6) Tsuda,H.: Hemophagocytic syndrome (HPS) in children and adults. Int, J. Hematol. 65 : 215-226, 1997.

7) Babu, T.G., et al. : Cytomegalovirus-associated hemophagocytic syndrome in a child with Crohn's disease receiving azathioprine. $J$. Pediatr.Gastroenterol. Nutr. 39:418-421, 2004.

8) Shirono, K., et al. : Adult T cell leukemia with cytomegalovirus associated hemophagocytic syndrome. Rinsho Ketsueki 35 : 177-182, 1994 [in Japanese, Abstract in English].

9) Yokoyama, T., et al. : Cytomegalovirus disease accompanied by severe hypoproteinemia in a patient with adult T-cell leukemia-lymphoma. Rinsho Ketsueki 37:358-361, 1996 [in Japanese, Abstract in English].

10) Karras, A., Thervet, E., Legendre, C. : Hemophagocytic syndrome in renal transplant recipients : report of 17 cases and review of literature. Transplantation 77 : 238-243, 2004.

11) Amenomori, M., et al. : Cytomegalovirus-associated hemophagocytic syndrome in a patient with adult onset Still's disease. Clin. Exp. Rheumatol. 23 : 100-102, 2005.

12) Sekiuchi, M., et al.: Hemophagocytic syndrome associated with hypercytokinemia in a patients with rheumatoid arthritis. Ryumachi $43: 696-702,2003$ [in Japanese, Abstract in English]. 
13) Van der Bij, W., et al. : Rapid immunodiagnosis of acute cytomegalovirus infection by monoclonal antibody staining of blood leukocyte. J. Med. Virol. 25 : 179-188, 1988.

14) Tanabe, K., et al. : Comparative study of cytomegalovirus (CMV) antigenemia assay, polymerase chain reaction, serology, and shell vial assay in the early diagnosis and monitoring of CMV infection after renal transplantation. Transplantation 64 : 1721-1725, 1997.

15) Tsuji, T., et al. : Cytomegalovirus antigenemia assay as a usual tool for early diagnosis and therapy for cytomegalovirus infection in three cases with collagen disease. Jpn. J. Clin. Immunol. 24 : 29-35, 2001 [in Japanese, Abstract in English]. 